\title{
Linking Entrepreneurial Activity to Economic Meltdown in Zimbabwe
}

\author{
Sophia Mukorera \\ School of Economics, University of KwaZulu Natal \\ Email: mukorera@ukzn.ac.za \\ Darma Mahadea \\ School of Economics, University of KwaZulu Natal \\ Email:mahadead@ukzn.ac.za
}

\section{Doi:10.5901/mjss.2014.v5n3p42}

\begin{abstract}
Understanding the relationship between entrepreneurship and key macroeconomic growth indicators is critical for generating growth and development in a normal or meltdown economy. The purpose of this study is to develop a model that best describes the relationship between the economic meltdown and the growth of micro and small-scale enterprises (MSEs) in Zimbabwe and to test the presence of refugee effects. Using annual data from 1980 to 2010, a multivariate Vector Error Correction Model (VECM) with the total number of MSEs, unemployment rate, inflation rate, liquidity (proxied by money supply) and real GDP as the dependent variables was run. The main finding of this study indicates the presence of refugee effects, albeit minimal, and that the growth in MSEs was partly because of the shortage of liquidity. Secondly, the relationship between unemployment and entrepreneurship is not linear but squared and positive in both instances.
\end{abstract}

Keywords: Entrepreneurship, economic meltdown, MSEs, refugee effect

\section{Introduction}

Entrepreneurship has been labelled as an engine for economic growth, contributing positively to employment creation and income generation. Accordingly, considerable emphasis is now being placed on encouraging the growth of micro, small-scale and medium-scale enterprises (SMMEs) in order to boost economic growth and development. SMMEs are found to be efficient and produce greater returns to the economy compared to large firms. Although entrepreneurial activity in developing nations (like in Africa) keep struggling to reap the economic benefits similar to those in developed nations, the number of enterprises and entrepreneurs continues to grow. Some authors believe that SMMEs in Africa are a sign of economic underdevelopment and others believe that it is the encouragement of SMME entrepreneurial activity that can take these economies out of their backwardness, if the right institutions and support networks are put in place (Ubogu, 2011; Englis, ver der Steen, Harms and Moore, 2012; Rusten and Bryson, 2007).

Zimbabwe experienced a period of economic meltdown during the period 1997-2008. This period of economic meltdown was accompanied by a steep growth in micro and small-scale enterprises (MSEs). This sudden growth in MSEs was not part of any major institutional reform; neither the government nor the international donors were actively supporting the growth of entrepreneurship and yet it still prevailed in the unstable economic conditions. Growth in entrepreneurial activity is related to economic growth through the entrepreneurial effect ${ }^{1}$ or can be an outcome of the refugee effect ${ }^{2}$. The goal of this study is to test whether the sudden growth in MSEs in Zimbabwe during the meltdown period was a result of the refugee effects.

The link between entrepreneurship and unemployment can be described as a two-way relationship. On the one hand, unemployment can lead to an increase in entrepreneurial activity (refugee 'push' effect). This happens as people with poor employment prospects venture into self-employment by starting a small business of their own out of necessity. On the other hand, entrepreneurship may create jobs leading to low unemployment because of the ability of individuals to identify market opportunities (entrepreneurial 'pull' effects). Individuals with the relevant skills are pulled into business by attractive market opportunities, creating enough jobs to reduce unemployment. Studies that have examined these effects

\footnotetext{
1 Entrepreneurial effect refers to a negative effect of self-employment or entrepreneurship on unemployment.

2 Refugee effect refers to a positive effect of unemployment on self-employment or entrepreneurship.
} 
found that the entrepreneurial effect definitely occurs and confirm its existence (Thurik, Carree, Van Stel and Audretsch, 2008; Audretsch, Carree and Thurik, 2001; Ghavidel, Farjadi and Mohammadpour, 2011). These studies, from both developed and developing nations, have ascertained the negative relationship between entrepreneurship and unemployment, that is, as entrepreneurial activity increases unemployment decreases. The role of entrepreneurship in economic development through employment creation has thus become a priority for many nations, and over the past three decades countries of the Organisation for Economic Cooperation and Development (OECD) have shifted their policies from being directed towards a "managed economy"3 to an "entrepreneurial economy"4 (Englis, ver der Steen, Harms and Moore, 2012).

There is a lot of ambiguity around the refugee effects. Both positive and negative relations have been picked up and the literature is still not conclusive on the impact of unemployment on entrepreneurship. It is important to establish the presence of the refugee effect when working with economies that are going through some crisis, especially if promoting entrepreneurial activity is part of a recovery plan. This study tests the relationship between unemployment and entrepreneurship as well as other macro-economic variables that characterise economic meltdown.

The primary objective of this study is thus to establish an econometric model that describes the relationship between MSE entrepreneurial activity and the economic meltdown in Zimbabwe. Secondly, the study analyses how quickly the MSEs adjust in response to any shocks (positive and negative) in the economy and analyses its implication for policy formulation.

\section{Entrepreneurship and Economic Growth}

The literature has conclusive evidence for the importance of entrepreneurship on economic growth, but its impact differs from country to country, depending mainly on its stage of economic development. The literature on the impact of entrepreneurship on economic growth suggests that a positive relationship is to be expected if the entrepreneur is defined as an innovator through creative destruction; or defined as a planner whose goal is to maximize profits; or as someone who possesses qualities that enables him or her to identify arbitrage opportunities; or as someone who creates means-ends frameworks for a new venture; or someone who possess exceptional qualities such as a high need for achievement (n-Ach), which is necessary for business success (Schumpter, 1934; McClelland, 1961; Kitzner, 1973; Cassons, 1982; Shane, 2003). Alternatively, entrepreneurs can contribute to economic growth through the introduction of new products, or by increasing competition through the introduction of variations on existing products, or by increasing market efficiency (Van Stel et al, 2008). As these activities are characteristic of entrepreneurial activity in many developed nations, a greater percentage of their growth in gross domestic product (GDP) is attributed to entrepreneurship.

Hussain, Sultan and llyas (2011) analysed the relationship between entrepreneurship and economic growth and found a positive relationship between entrepreneurship and GDP and employment. Parker and Robson (2004) found a positive correlation between GDP per capita and entrepreneurship from a panel data analysis of 12 OECD countries. Thurik et. al. (2008) estimated the relationship between self-employment (entrepreneurship) and unemployment in a twoequation vector auto regression model using data from 23 OECD countries and found that there are stronger entrepreneurial effects than refugee effects. The stronger entrepreneurial effects contribute positively to economic growth.

The finding that the entrepreneurial effect contributes to economic growth is supported by many researchers, but the refugee effect is not clear. Thurik et. al (2008) for example, found that unemployment is positively associated with new business start-ups, but Audretsch and Fritsch (1994) found a negative relationship, whilst Carree, Van Stel, Thurik and Wennekers (2001) found no statistically significant relationship between the two. Although there is evidence to support the positive relationship between entrepreneurship and unemployment, there is also evidence suggesting that the relationship is not linear. High unemployment can reduce entrepreneurial activity and in such circumstances the refugee effect may not exist (Audretsch et. al., 2001; Ghavidel et. al., 2011). The negative relationship could emanate from the high exit rates or low survival rate of new businesses because unemployed people are likely to possess lower endowments of human and social capital, and lower levels of personal wealth and entrepreneurial talent (Thurik,2007;

\footnotetext{
${ }^{3}$ According to Van Stel (2005:331), a managed economy is the political, social and economic response to an economy dictated by forces of large-scale production, reflecting predominance of the production factors of capital and (unskilled) labour as the source of competitive advantage.

${ }^{4}$ Entrepreneurial economy is the political, social and economic response to an economy dictated not only by the dominance of the production factor of knowledge, but also by the presence of entrepreneurial activity to accommodate knowledge spillover.
} 
Lucas, 1978). High unemployment rates correlate with low economic growth leading to low entrepreneurial activity (Baptista, Van Stel and Thurik, 2006). It is against this background that in this study the relationship between entrepreneurial activity and unemployment, real GDP, low liquidity (proxied by money supply) and inflation (economic meltdown indicators) is tested in the context of Zimbabwe, using a Vector Error Correction Model (VECM).

\section{Economic Meltdown in Zimbabwe}

Economic meltdown has no straight definition, but it can be explained in terms of its characteristics. The New Oxford Dictionary defines the figurative use of meltdown as, "a disastrous event especially a rapid fall in share prices". Capozzi (2010) characterises economic meltdown as a crisis that is a result of intertwined factors namely high unemployment, no liquidity, hyperinflation, lack of consumer confidence and the falling of the stock market and real GDP5. Wolfe and Wolfe (2012) identifies the major causes of an economic meltdown as speculation, currency devaluation, natural and manmade disasters, and political conflicts. All these elements characterised the Zimbabwean meltdown situation from 1999 to 2008. The meltdown in Zimbabwe started in 1997, being triggered by the effects of the Economic Structural Adjustment Programme (ESAP) implemented in 1991, the crashing of the stock market in 1996, and the deliberate actions of its political leaders, among other things (Richardson, 2005; Moss, 2007). However, it was in 1999 when the inflation grew above $50 \%$, marking the beginning of the period of hyperinflation and compounding to the economic meltdown.

At independence in 1980, the new Zimbabwean government inherited an industrialised and diversified economy that was mainly driven by the manufacturing and agricultural sectors. Agriculture remained the backbone of the economy until late 1990s when the sector was distorted by the land invasions that were spearheaded by 'war veterans ${ }^{6}$ '. These land invasions coupled with the aftermath of the Economic Structural Adjustment Programme implemented from 1990 to 1995, and the high government budget deficits resulting from the government's involvement in the war in Democratic Republic of Congo (DRC) in 1996, and the awarding of high pay-outs to veterans of the liberation war, and political imbalances experienced between 1996 and 2008, have fuelled the economic meltdown (Coltart, 2008; Games 2002; Matandirani, 2011; Magaisa, 2009). The deficit was exacerbated by the huge decline of export revenue from the agricultural sector and excessive money creation causing subsequently high inflation. Other factors that contributed to the meltdown were the economic distortions caused by price regulations and the misalignments of the foreign exchange rate. This distortion created a black market, which ended up operating in nearly all economic activities in Zimbabwe. The situation was worsened by the erosion of property rights and entrepreneurial freedom; the imposition of international sanctions, such as travel restrictions on the country's elite; the decline in foreign direct investment (FDI) inflows; and lack of access to credit and balance of payment support from agencies such as the International Monetary Fund (IMF) and the World Bank (Luebker, 2008:17; Matandirani, 2011; Magaisa, 2009; Ishengoma and Kappel, 2006; Sichone, 2003; Games, 2002, Moore, 2001).

The economic collapse plunged most Zimbabweans into poverty, as the country had a $72 \%$ poverty headcount ratio below the national poverty line in 2004 (World Bank, 2011). Many people lost their jobs as companies retrenched staff and others even closed (Coltart, 2008; Magaisa, 2009). The meltdown manifested itself in the form of skyrocketing unemployment, shortages of basic commodities, shortages of cash in banking institutions, growth of the black market, deterioration of the health system and infrastructure, and increased migration to neighbouring countries and beyond (Coltart, 2008; Games, 2002). All these factors contributed to the high poverty levels in the country.

\section{The Rise of Micro and Small-Scale Enterprises (MSEs)}

In the midst of all the chaos created by the meltdown, the number of MSEs grew steeply. Prior to independence in 1980, there were few black entrepreneurs in Zimbabwe. Since 1980, small-scale entrepreneurship has always been advocated under the banner of 'black empowerment'. The new government provided some incentives to encourage the establishment of new entrepreneurs, but the rate at which new firms were being formed was slow until the late 1990s when the pace picked up. The slow growth in MSEs has been pinned on the poor policies that failed to support them financially and protect them from taxes (Matandirani, 2011; Kapoor, Mugwara and Chidavaenzi, 1997). The total number of formally registered MSEs grew from 5110 in 1980 to 10841 in 1986 and then dropped to 9610 in 1990. Between 1990

\footnotetext{
5 The four macro-economic indicators identified in this definition of economic meltdown will be used later on in modelling the relationship between economic meltdown and growth in MSEs.

${ }^{6}$ War veterans are the veterans that participated in the liberation struggle.
} 
and 1999 the total number was almost constant, dropping slightly to a total number of 8894 in 1999. Going forward, the number started growing steeply, climbing from 11069 in 2002 to 85210 in 2008 (Labour Statistics, 2006; Harare City Council Yearly Report, 2010). During the economic meltdown period (1999-2008), MSE entrepreneurial activity increased by approximately 8 times more than during the post-independence period of 1980-1998.

This significant change in growth in entrepreneurship came at a time when the Zimbabwean economy was struggling, between 1999 and 2008. Inflation reached a record high of 14.1 billion \% in 2008, from 58\% in 1999 and from 24\% in 1996 (World Bank, 2011). Although money supply was growing over the same period, its growth rate was slow to match the escalating inflation rate creating liquidity shortages. The unemployment rate rose from $7 \%$ in 1996 to $46 \%$ in 1999 and $80 \%$ in 2008. The total numbers of MSEs, unemployment, money supply and inflation, all have a similar rising trend, which suggests a possible relationship between these variables. It is this relationship that this paper seeks to investigate to see if there is an association between economic meltdown and entrepreneurial activity, and to produce a model that can explain the rise of entrepreneurial activity especially during the economic meltdown period.

\section{Data and Methodology}

From the previous sections, the definition of economic meltdown suggests that the relationship between entrepreneurship and economic meltdown can be tested using four macro-economic variables, namely unemployment, real GDP, money supply and inflation. The literature also suggests that the relationship between entrepreneurship and unemployment is two way. Firstly, increases in entrepreneurial activity can lead to a decrease in subsequent unemployment (entrepreneurial effect), and secondly, increases in unemployment lead to an increase in subsequent entrepreneurial activity (refugee effect). The fact that the relationship between entrepreneurship and unemployment is dynamic makes it inappropriate to use a simple Ordinary Least Squares (OLS) model. Some of the explanatory variables mentioned above are also endogenous, like unemployment and inflation in the Phillips curve. These relationships form a number of simultaneous equations which need to be part of this analysis. Previous researchers have also shown the presence of lagged responses when looking at the relationship between these economic variables and entrepreneurial activity (Thurik et. al., 2008).

A model that allows us to analyse reverse causality using simultaneous equations, analyses both the short-run and long-run dynamics and includes time lags, is a Vector Autoregressie Model (VAR Model) or a Vector Error Correction Model (VECM) (Mertler and Vanatta, 2002; Bjornland, 2000) ${ }^{7}$. Unlike the traditional macro-econometric models that require the imposing of restrictions in classifying variables as endogenous or exogenous, a VECM model treats all variables as endogenous and explains the change in $y$ using one lagged level of $y$ and $x$, and one or more lagged differences of $y$ and $x$ (Bjornland, 2000). For this study, a VECM was developed and run in STATA using the Johansen technique ${ }^{8}$. Some exogenous variables, in the form of dummy variables, were also included so as to capture the impact of structural breaks.

All the data sets of the five endogenous variables were found to be non-stationary and only become stationary after first differencing, thus are I(1). The maximum lags to be included in the model were identified as only one, using the Schwarz's Bayesian information criterion (SBIC). In time series analysis, running a multivariate model with non-stationary variables is likely not to produce sound results unless there is evidence of cointegration. The presence of cointegration is a sign that there is long-run equilibrium. To test for cointegration, the Johansen test for cointegration was used. The test identified the presence of 1 cointegrating vector. With a trace statistic of 1.5759 that is less than the $5 \%$ critical value of 15.41, we failed to reject the null hypothesis of maximum rank of 1 or less. The max-eigenvalue also indicated 1 cointegrating equation at the $5 \%$ level of significance. This cointegrating equation was normalised on the entrepreneurial equation suggesting that the study only tests for the refugee effect.

The VECM model in this study reads as follows:

$\Delta$ LMSE $_{\mathrm{t}}=\alpha_{0}+\delta_{1} \mathrm{~S}_{\mathrm{t}}+\delta_{2} \mathrm{D}_{\mathrm{t}}+\delta_{3} \mathrm{D} 2_{\mathrm{t}}+\lambda\left[\beta_{1}\right.$ LMsupply $_{\mathrm{t}}+\beta_{2}$ Unemp $_{\mathrm{t}}+\beta_{3}$ Inflat $\left._{\mathrm{t}}+\beta_{4} \mathrm{LRGDP}_{\mathrm{t}}-\mathrm{LMSE}_{\mathrm{t}}\right]+\varepsilon_{\mathrm{t}}$ where LMSE is the log of total number of MSEs at a given time t, $\Delta$ is a first difference operator, LMsupply is log of money supply, Unemp is the unemployment rate, Inflat is the inflation rate, LRGDP is log of real GDP, D1 and D2 are dummy variables for the meltdown period and chaos inflationary period, respectively, S1 is a structural break, superscript $S$ is short run, superscript $L$ is long run, $\alpha, \beta$ and $\delta$ are unknown parameters to be estimated. $\lambda$ is the adjustment

\footnotetext{
${ }^{7}$ Economics defines a short run as a time period in which only variable costs can be adjusted, and a long term as a time period in which both variable and fixed costs can be adjusted.

8 The Johansen technique allows us to determine the lag length and determine the number of cointegration vectors in a few steps without imposing any restrictions.
} 
parameter capturing the speed of adjustment back to long-run equilibrium following a shock. The coefficient for $\lambda$ should be negative and between 0 and 1 . The closer the adjustment parameter is to 1 , the faster the speed of adjustment (Engel and Granger, 1987).

To analyse the relationship between formal sector entrepreneurship and economic meltdown, annual time series data from 1980 to 2010 were sourced from the World Bank website, CIA World Factbook website, Zimbabwe Central Statistics Office, Harare City Council and the Economic Information Services for Zimbabwe Statistics website ${ }^{9}$. The study was restricted to the formal sector only, due to the absence of a full data set for the informal sector. Table 1 below gives a brief description of all the variables that were used in the study.

Table 1: Description of the variables in the VECM model

\begin{tabular}{|c|c|c|}
\hline Variable & $\begin{array}{l}\text { Variable } \\
\text { name }\end{array}$ & Description of variable \\
\hline Entrepreneurship & LMSE & $\begin{array}{l}\text { The head count of total number of micro and small-scale firms in the formal sector with } 50 \\
\text { employees or less in a specific year. The data excludes agricultural firms from large-scale } \\
\text { commercial farmers and ARDA. Data was log transformed. }\end{array}$ \\
\hline $\begin{array}{l}\text { Unemployment } \\
\text { Rate }\end{array}$ & Unemp & $\begin{array}{l}\text { The percentage of the labour force that was without jobs in a specific year. For this study the } \\
\text { broad definition of unemployment (any person aged between } 15 \text { and over and was either } \\
\text { without a job, or was available for work, or was looking for work over the previous } 12 \text { months) } \\
\text { was counted as unemployed. }\end{array}$ \\
\hline Real GDP & LRGDP & Real Gross Domestic Product of Zimbabwe from 1980 to 2010. Data was log transformed. \\
\hline Inflation Rate & Inflat & Annual inflation rate of Zimbabwe from 1980 to 2010. \\
\hline Money Supply & LMsupply & $\begin{array}{l}\text { Money and quasi money (M2) in constant US\$ currency from } 1980 \text { to 2006. Data was log } \\
\text { transformed. }\end{array}$ \\
\hline Structural Break & S1 & $\begin{array}{l}\text { Structural break dummy assuming value } 1 \text { in } 1999 \text { and } 0 \text { otherwise. } 1999 \text { was the year when } \\
\text { the opposition party MDC was formed, starting a period of political instability in the country, the } \\
\text { first draft constitutional referendum was presented, and this was the year when inflation rose } \\
\text { above } 50 \% \text {, commencing the period of hyperinflation leading to the meltdown. }\end{array}$ \\
\hline Meltdown Dummy & D1 & $\begin{array}{l}\text { Dummy captures the period of the meltdown (when inflation was above } 50 \% \text { but below } 1000 \% \text { ), } \\
\text { assuming value } 1 \text { from } 1999 \text { to } 2008 \text { and } 0 \text { otherwise }\end{array}$ \\
\hline Chaos Dummy & D2 & $\begin{array}{l}\text { Dummy captures the period when inflation was above } 1000 \% \text {. Assumes a value } 1 \text { from } 2006 \text { to } \\
2008 \text { and } 0 \text { otherwise. This period was characterised by no liquidity, a very active foreign } \\
\text { currency black market and severe shortages of basic commodities }\end{array}$ \\
\hline
\end{tabular}

\section{Results and Discussion}

To avoid a multicollinearity problem between real GDP and inflation, two models were run and the results were compared. The first model (Model 1) included entrepreneurship, money supply, unemployment and inflation. The second model (Model 2) replaced inflation with real GDP.

Table 2: ECM Results for Entrepreneurship models

\begin{tabular}{lll}
\hline $\begin{array}{l}\text { With } 1 \text { lag } \\
\text { Dependent Variable: Growth in MSEs }\end{array}$ & \\
\hline Variable & $\begin{array}{l}\text { Model 1 } \\
\text { with Inflation }\end{array}$ & $\begin{array}{l}\text { Model 2 } \\
\text { with RGDP }\end{array}$ \\
& Long-term & Long-term \\
\hline Unemp & $0.0291^{* *}$ & $0.049^{* * *}$ \\
& $-0,015$ & $(0,007)$ \\
Inflat & $1.55 \mathrm{e}-09^{* * *}$ & \\
LMsupply & $(9.36 \mathrm{e}-11)$ & $1.257^{* * *}$ \\
LRGDP & $0.944^{* *}$ & $(0,267)$ \\
& $(0.433)$ & $-1.43 \mathrm{e}-08^{* * *}$
\end{tabular}

${ }^{9}$ Quarterly data was the most desired data set for this study but due to unavailability of quarterly data for total number of MSEs, it could not be used. 


\begin{tabular}{|c|c|c|}
\hline \multirow{3}{*}{ Constant ( $\alpha 0)$} & & $(0,000)$ \\
\hline & 0,024 & $0.6094^{* * *}$ \\
\hline & $(0,036)$ & $(0,141)$ \\
\hline \multirow[t]{2}{*}{ D1 } & $-0,043$ & $-0.4987^{* * *}$ \\
\hline & $(0,074)$ & $(0.201)$ \\
\hline \multirow[t]{2}{*}{ D2 } & $0.3537^{* * *}$ & -0.097 \\
\hline & $(0,112)$ & $(0.272)$ \\
\hline \multirow[t]{2}{*}{ S1 } & 0,096 & $0.7381^{*}$ \\
\hline & $(0,171)$ & $(0.418)$ \\
\hline$\lambda$ & $-0.0956^{* * *}$ & $-0.3352^{* * *}$ \\
\hline R-squared & $89,83 \%$ & $50,93 \%$ \\
\hline
\end{tabular}

The results reported in Table 2 above are a simulation of MSE growth in the formal sector in Zimbabwe. Model 1 results show that there is a positive and statistically significant relationship between MSE growth and money supply (0.944), inflation (1.55e-09), unemployment (0.0291) and the chaos period (D2) (0.3537). A 1\% increase in the shortage of liquidity (as proxied by money supply) results in a $0.9 \%$ increase in the total number of MSEs, holding all other things constant. This relationship is statistically significant at a $5 \%$ level of significance. The same positive relationship was also found between unemployment and inflation, although the magnitude is smaller. A $1 \%$ increase in unemployment was found to result in $0.03 \%$ increase in MSEs. The chaos period also contributed significantly to the growth in MSEs, accounting for about $42.43 \%{ }^{10}$ of the change in total number of MSEs. The positive relationship with the explanatory variables supports previous findings by other researchers of a refugee effect (Thurik et. al., 2008; Ghavidel et. al., 2011). However, in this case the refugee effect is emanating to a greater extent from the shortage of liquidity and to a lesser extent from unemployment. This model has a goodness of fit of $89.83 \%$.

Although not significant, the meltdown period (D1) accounts for approximately $4.21 \%$ of the variation in MSEs growth. An adjustment coefficient of -0.0956 implies that only $9,56 \%$ of the variation will be corrected in the first year, thus it will take about 10.46 years for the economy to adjust back to the long-run equilibrium defined by Model 1 , following a shock in the economy. A period of $10.46(1 / 0.0956)$ years is perhaps too long for the adoption of any policy that employs variables used in this model as instruments. This long period of adjustment reflects the instability that was in the economy due to the meltdown and can also be defined as a measure of "loss of confidence" in the system as a whole. Model 1 explains a state of abnormality surrounding the sudden growth in micro and small-scale entrepreneurial activity in Zimbabwe.

Model 2 presents a slightly different picture. The positive relationship, which shows the refugee effect, is again picked in this model between MSE growth and unemployment (0.049) and money supply (1.257). A $1 \%$ increase in the shortage of liquidity result in $1.257 \%$ increase in the total number of MSEs, holding all other things constant. A $1 \%$ increase in unemployment results in a $0.05 \%$ increase in the total number of MSEs, holding all other things constant. These two relationships are statistically significant at a $5 \%$ level of significance. MSE growth is negatively related to real GDP. A $1 \%$ decrease in real GDP tends to result in a $0.0000000143 \%$ increase in MSEs, holding all other things constant. Although there is significant relationship between real GDP and MSE growth, the coefficient is extremely small. The structural break (S1) is also statistically significant and explains about 109.19\% change in MSEs growth. The dummy for the meltdown period is also statistically significant at $1 \%$ level and explains $39.26 \%$ of the MSEs growth. The constant (0.6094) is statistically significant at a $1 \%$ level of significance, suggesting that there are some variables that are not included in the model that can explain the variation in MSE growth. The adjustment period in this model is 2.98 years and this model explains about $50.93 \%$ of the variation in MSE growth.

Comparing Model 1 and Model 2, Model 1 has a better fit than Model 2 as shown by the R-squared. However, both models show that the growth in entrepreneurial activity among the micro and small-scale entrepreneurs was mainly for survival. Entrepreneurship was used as an alternative source of income and also an alternative source of liquid cash. The failure by the formal financial intermediaries to meet the demand for money drove people into cash-generating micro and small-scale entrepreneurial activities that use paper money as a medium of exchange.. Entrepreneurship was to a lesser extent used for its refugee effect from unemployment, but rather to cater for the "cash at hand" necessity. Thus the type of entrepreneurship that has been prevailing in Zimbabwe is more of a necessity-driven entrepreneurship. Model 1 provides a better fit in explaining the link between the growth in MSEs and the economic meltdown in Zimbabwe.

10 To interprete the coefficient on a dummy, the following formula is used, $\left(e^{\beta-1}\right) \times 100$. 
As pointed out earlier, previous studies have shown that the refugee effects may not be certain under circumstances of high unemployment. Some studies picked up a negative relationship between unemployment and entrepreneurship and this is not consistent with refugee effect (Baptista et. al., 2006; Audretsch et. al., 2001). To test for the impact of excessive unemployment, a squared unemployment variable was introduced to the model. The results are presented in Table 3 below.

Table 3: VECM results with squared unemployment variable

\begin{tabular}{|c|c|}
\hline \multirow{3}{*}{ Variable } & Dependent Variable: Growth in MSEs \\
\hline & Model 3 with Inflation \\
\hline & Long-term \\
\hline Unemp & $\begin{array}{l}0.0008 \\
(0.017)\end{array}$ \\
\hline Unemp2 & $\begin{array}{l}0.0004^{* *} \\
(0.0002)\end{array}$ \\
\hline Inflat & $\begin{array}{c}6.53 \mathrm{e}-10^{* * *} \\
(3.73 \mathrm{e}-11)\end{array}$ \\
\hline LMsupply & $\begin{array}{c}0.3910^{\star *} \\
(0.181)\end{array}$ \\
\hline LRGDP & \\
\hline Constant (a0) & $\begin{array}{l}0.0223 \\
(0.036)\end{array}$ \\
\hline D1 & $\begin{array}{c}-0.182^{\star \star *} \\
(0.073)\end{array}$ \\
\hline D2 & $\begin{array}{c}0.285^{* * *} \\
(0.110)\end{array}$ \\
\hline s1 & $\begin{array}{l}0.1994 \\
(0.169)\end{array}$ \\
\hline$\lambda$ & $-0.2138^{\star * *}$ \\
\hline R-squared & $90.22 \%$ \\
\hline
\end{tabular}

Note: ${ }^{* \star *} 1 \%$ level of significance, ${ }^{* \star} 5 \%$ level of significance, ${ }^{*} 10 \%$ level of significance. Numbers in () are standard deviations

The introduction of the squared unemployment variable confirmed the initial findings of the presence of the refugee effect. A positive relationship between unemployment and entrepreneurship is picked up in both unemployment (Unemp: 0.0008) and unemployment squared (Unemp2: 0.0004) variables although Unemp has a higher coefficient than Unemp2. Refugee effects come out further with the squared unemployment. The smaller coefficient on Unemp2 could be for the reason that a higher unemployment level may imply a lower capital base, which reduces the chance of new enterprises being formed and surviving. In other words, greater unemployment stimulates start-up activity due to the need for survival, but most of them may not survive because of a poor initial capital base (Reynold, Miller and Makai, 1995).

Money supply and inflation still have a positive relationship with MSEs growth. The meltdown period explains $16.64 \%$ whilst the chaos period explains approximately $32.98 \%$ of the growth in MSEs. An adjustment coefficient of 0.2138 means that it will take approximately 4.68 years to restore long-run equilibrium following any shock. This low speed of adjustment still makes it difficult to utilise any of the variables in the model as policy instruments to fast track or boost entrepreneurship and growth.

\section{Conclusion and Policy Recommendations}

Of the three models that were tested in this study, the one that best describes entrepreneurial activity during economic meltdown in Zimbabwe is Model 3. Entrepreneurial activity in the formal sector in Zimbabwe was to a greater extent driven by the absence of liquidity as well as the absence of formal employment opportunities. During the meltdown period, financial institutions ran dry of cash and most people could not withdraw their incomes or savings from the banks. Failure by the financial intermediaries to supply enough bank notes drove people into entrepreneurship where they traded in exchange for a hard currency like the US dollar. Entrepreneurship was used as an alternative way of getting the hard currency to use in activities such as paying for taxi fares, buying basic commodities from the informal sector or 
paying for basic goods. The positive relationship between squared unemployment and entrepreneurship shows the presence of the refugee effect, although it is minimal.

Money supply and MSE growth are strongly correlated and money supply contributed the most to the growth of MSEs. Not having enough money supply to meet the transactionary demands, owing to the hyperinflation, caused a liquidity constraint, and this pushed many people into micro and small-scale entrepreneurial activity as an alternative source of cash. This model has an adjustment period of 4.68 years $(\lambda=-0.2138)$, which is deemed too long. The adjustment period can be interpreted as a measure of "loss in government confidence" and the system as a whole. The failure to quickly adjust to shocks in the system could be because of the entrepreneurs' choice to ignore the system as they felt the government could not provide for their employment or basic needs. With this slow speed of adjustment, it means that even when the government implements policies directed towards boosting entrepreneurial activity, the intended effects of the policy might not transmit fast into the economy.

Unless changes are made through improvements in incentive structures to the MSEs and improvements in the institutions, micro and small-scale entrepreneurial activity in Zimbabwe will mostly be used for immediate survival without much benefit to the country. It is apparent that these MSEs were an integral forced activity in the lives of the people of Zimbabwe during the time of crisis. As the country now recovers from the effects of the meltdown, these MSEs can be used as tools in the recovery process. Policy makers should formulate incentive structures that encourage the growth of already existing MSEs so that they can move from being micro and small-scale to medium-scale businesses, and in so doing create employment and income opportunities for the country. A lot of jobs can possibly be created by improving on already functioning enterprises rather than seeking to encouraging the creation of new enterprises that may take longer to become operational because of the adjustment lags $(\lambda)$, ranging from 4.68 to 10.4 years.

\section{References}

Audretsch D.B., Carree M.A., \& Thurik A.R. (2001). Does entrepreneurship reduce unemployment? Tinbergen Institute discussion paper T IOL-074/30. Erasmus University Rotterdam.

Audretsch D.B., \& Fritsch M., (1994). The Geography of firm births in Germany. Regional Studies, 28(4), July, 359-365.

Baptista R., Thurik R., \& Van Stel A.J., (2006). The relationship between entrepreneurship and unemployment in Portugal. Technological forecasting and Social Change 74, 75-89

Bjornland H.C., (2000). VAR Models in Macroeconomic Research, Statistics Norway, vol 14

Capozzi C. (2010). Define Economic Meltdown, eHow Contributor, updated June 27, 2010 http://www.ehow.com/about_667123_defineeconomic-meltdown.html

Carree M., Van Stel A.J., Thurik R., Wennekers S., (2001). Economic development and business ownership: An analysis using data of OECD countries in the period 1976-1996. Small Business Economics

Casson M. (1982). The Entrepreneur: An Economic Theory. Oxford

CIA Factbook (2011). The World Factbook, www.cia.gov

Engel and Granger, (1987). Cointegration and Error Correction: Representation, Estimation and Testing, Econometrica, vol 55 pg 251 276

Englis P., ver der Steen M., Harms R., and Moore R.A., (2012). Entrepreneurial activity, the economy and the importance of small firms. In Deakins D. \& Freel M., (Eds), Entrepreneurship and Small Firms (pp 31-55). McGraw-Hill Higher Education, Berkshire

Games D., (2002). The Zimbabwe Economy: how has it survived and how will it recover? South African Institute of International Affairs. Issue 30

Ghavidel S., Farjadi G., \& Mohammadpour A., (2011). The relationship between entrepreneurship and unemployment in developed and developing countries, International Conference on Applied Economics- ICOAE

Harare City Council Yearly Report, 2010 (unpublished)

Harris R.D., (1994). Cointegration Analysis using Johansen Technique: A Practioner's Guide to the software. The Economic Journal, vol 104, No.426 pp. 1227-137

Hussain M.F., Sultan J., Ilyas J., (2011). Entrepreneurship and economic growth, Interdisciplinary Journal of Contemporary Research in Business, vol 2. No. 12

Ishengoma E. \& Kappel R. (2006). Economic Growth and Poverty: Does formalization of informal enterprise matter? Working Paper no.20 German Institute of Global and Area Studies.

Kapoor K., Mugwara D., Chidavaenzi I., (1997). Empowering Small Enterprises in Zimbabwe, World Bank Discussion Paper no. 379

Labour Statistics, 2006, Zimbabwe Government Printers, Zimbabwe

Luebker M. (2008). Employment, unemployment and informality in Zimbabwe: concepts and data for coherent policy-making. ILO subregional office fro Southern Africa. Issue paper no. 32

Magaisa A.T., (2009). Zimbabwe: Sanctions, the economy and democratic process. NewZimbabwe.com, published 11/12/2009

McClelland D., (1953). The Achievement Motive, Appleton-Century-Crofts, New York

Mertler and Vanatta, (2002). Advanced and Multivariate Statistical Methods: Practical Application and Interpretation. McNaughton and 
Gunn, Inc

Moore D., (2001). Is the Land the Economy and the Economy the Land? Primitive Accumulation in Zimbabwe, Journal of Contemporary African Studies, 19:2, 253-266

Moss T., (2007). Zimbabwe's Meltdown: Anatomy of a Peacetime Economic Collapse, The Fletcher Forum of World Affairs Vol31:2 pg. 133-148 www.fletcher.tuffs.edu/../moss.pdf

Parker, S. C. \& Robson, M. T. (2004). Explaining international variations in self-employment: evidence from a panel of OECD countries. Southern Economic Journal, 71, 287-301.

Reynolds, P., Miller, B., \& Maki, W.R. (1995).Explaining Regional Variation in Business Births and Deaths: U.S. 1976-1988. Small Business Economics, 7 (5), 389-707.

Richardson C. (2005). "The Loss of Property Rights and the Collapse in Zimbabwe," Cato Journal 25 (3): 560-562.

Rusten, G. \& Bryson, J. R. (2007). The production and consumption of industrial design expertise by small and medium size firms: some evidence from Norway. Geografiska. Annaler, 89B (S1), 75-87

Sichone O. (2003). Zimbabwe's Economic Policies, 1980-2002. DPMN Bulletin: volX(2)

Schumpeter J.A., (1934). The Theory of Economic Development: An Inquiry into Profits, Capital Credit, Interest and the Business Cycle, Cambridge, MA, US: Harvard University Press

Shane S., (2003). A General Theory of Entrepreneurship: The Individual-Opportunity Nexus, Cheltenham, UK, Northampton, MA, USA

Thurik A., Carree M., van Stel A., Audretsch D., (2008). Does Self-Employment Reduce Unemployment, Journal of Business Venturing, Volume 23, Issue 6, pp 673-686

Ubogu A.E. (2011). Determinants of the Locational Decisions of Informal Sector Entrepreneurs in Urban Zaira. Journal of Geography and Geology, vol.3(1)

Wolfe R.W and WolfeS.M. (2012) Chronicles of a financial crisis: causes and ethical dimensions. Teaching Ethics, Spring 2012, DePaul University, Georgetown University.

World Bank. (2011). Africa Development Indicators 2011, http://data.worldbank.org/sites/default/files/adi_2011-web.pdf downloaded on 23/02/2012 